\title{
鋼素材特性を反映させた鋼構造部材の塑性変形能力評価に関する研究 A STUDY ON ESTIMATE FOR PLASTIC DEFORMATION CAPACITY OF STEEL MEMBERS REFLECTED MATERIAL PROPERTIES
}

\author{
鈴木 敏 郎*，五十嵐 規矩夫**，薩川 恵 一*** \\ Toshiro SUZUKI, Kikuo IKARASHI and Keiichi SATSUKAWA
}

\begin{abstract}
This paper describes estimation method for plastic deformation capacity of steel members. When we estimate steel members with present recommendation, it is difficult to say that we can estimate plastic deformation capacity of steel member between some kinds of steel. Because this recommendation do not consider modulus in plastic region. So we suggest new recommendation to contain the factor of material properties in the plastic region. We compare the estimate method of this study with the estimate method of the present recommendation. As a result, the method of this study is showing a good correspondence between some kinds of steel.
\end{abstract}

Keywords : material property, member, plastic deformation capacity, local, buckling, yzeld stress 素材特性, 部材, 塑性変形能力, 局部座屈, 降伏応力度

$\S 1$. 序

鋼素材特性を把握するための因子としては，上下降伏応力度，降 伏棚の有無, ‘Uずみ硬化勾配, 引張強さ, 一様伸び, 降伏比等が挙 げられる。このように鋼材の素材特性を反映する上で様々な因子が あるにも関わらず，塑性変形能力などの部材性能評価に用いられる 鋼材の機械的性質としては，降伏応力度を用いることが主流である。 また文献 1 )では建築構造用部材が塑性変形能力を向上するための 材料特性の一つとして降伏比をあげ.ている。降伏比を低く抑之るこ とにより部材の塑性化領域が拡大し，それに伴い部材の塑性変形能 力が大幅に向上するとしている2》。こような流れの中で, 著者等は 塑性域での応力Uずみ経路が同じものの降伏点付近の経路の異なる 2 種類の鋼材を対象として，梁の載荷実験および数值解析を行い, 2 種類の鋼材の性状について検討している ${ }^{3)}$ 。その結果, 梁の無次元 化荷重変位関係にお心て最大耐力, 最大耐力時変位量に大きく差が 生じるものの実体の荷重変位関係において差異はみられないという 知見を得た。この知見から著者らは単に降伏応力度のみで塑性変形 能力を評価するのではなく, 部材の塑性変形能力を決定すると思わ れる塑性域での材料特性を反映させた形で, 部材の塑性変形能力を 評価する必要があると考える。そこで文献 4 ）では，この 2 種類の鋼 材からなる部材を統一的に評価することを検討している。そして塑 性変形能力を評価する際の評価因子として，鋼材の塑性域を反映さ せた二次勾配と新たな降伏応力度を提案し，その評価因子により修 正している幅厚比を用いて塑性変形能力を評価した結果, 降伏応力 度のみを用いて幅厚比を修正する従来の方法に比べてばらつきが少 なく，その有効性を確認している。文献 4 )では塑性域での応力ひず
み経路が同一の 2 種類の鋼材を対象としたが，本研究では塑性域で の応力Uずみ経路や降伏点が異なる各種鋼材に対象領域を広げて, 文献 4 )で提案している評価方法により各種鋼材を用いた部材の塑 性変形能力を整理することを目的とする。

近年では，建築構造用の鋼材として，様々な鋼材が開発され，そ の使用に関しても実用化の段階にきている。部材の塑性変形能力を 確保するために, 各種指針において幅厚比規定が設けられているが， 各種鋼材を用いた場合の幅厚比規定に対しては, 文献12）を参考にす れば，SS400材を用いた場合の幅厚比規定に F 值を用いて換算して 規定しているのが現状であろう。あくまでも使用される鋼材特性と しては降伏応力度のみであり，塑性域の鋼材特性が反映された形で 幅厚比規定がなされていない。これはいかなる鋼材を用いた場合に おいても, 降伏応力度あるいは $\mathrm{F}$ 值で部材の塑性変形能力評価が可 能であるという考えに基づいている。現行の降伏応力度を規定する 時には上下降伏点で取る場合， $0.2 \%$ オセット法で取る場合など, 応力度Uずみ度関係における降伏棚の有無や経路の違いにより，そ の都度異なっている。

しかし文献 4 )でみたように, 耐震設計上必要とされる塑性変形能 力を有するための幅厚比の範囲では, 鋼材の塑性域での応力度Uず み度曲線が同一である時に降伏点付近の経路の違いが塑性変形能力 に及ほす影響は少なく，降伏応力度のみを塑性変形能力評価に用い ることは，部材の統一的な評価を行う上で困難を伴う結果となる。 従って各種鋼材を用いた部材の塑性変形能力を統一的に評価するた めには，個々の鋼材の塑性域におけ、る特性を反映させることが必要 であり，文献 4) で提案している手法が有効であると考える。
* 侏構造材料研究会 代表. 工博

** 東京工業大学工学部建築学科 助教授・博士 (工学)

*** 東京工業大学大学院博士後期課程 修士 (工学)
Kouzouzairyou Kenkyukai, Co , Ltd, Representative, Dr. Eng

Assoc Prof, Dept of Architecture, Faculty of Engineering, Tokyo Institute of Technology, Dr Eng

Graduate Student, Tokyo Institute of Technology, M Eng 
本研究では各種鋼材を用いた部材の塑性変形能力を統一的に評価 することを目的とするが，その際鋼材の塑性域における剛性をどの ように評価するのかが問題となる。文献 4 )ではその基本的な考え方 について示しているが, 本研究においてもその考えに基づき, 部材 が最大耐力を迎えた時点における圧縮フランジ軸方向ひずみ度を参 考にし, 評価に用いる際の鋼素材の塑性域における剛性を得る。これ を各種鋼材について求め, 文献 4 ) で提案する降伏応力度と二次勾配を 用いて, 各種鋼材を用いた部材の塑性変形能力を統一的に評価する。

様々な鋼材を用いた部材の塑性変形能力を統一的に評価するとい う観点にたった研究としては，小野等の一連の研究がある ${ }^{5) ~}$ 。これ らの研究では, 鋼材の修正補エネルギーに着目し, 部材の塑性変形 能力を統一的に評価する指標として提案している。

まず本研究では, 簡単な板の数值解析を通して, 降伏応力度と塑 性化後の二次勾配が, 部材の塑性変形能力にどのような影響を及ぼ すかを検討し，塑性変形能力の評価を行う時には二次勾配を考虑に 入れる必要があることを示す。そして現在建築用鋼材として使用さ れている，あるいは使用が検討されている鋼材の機珹的性質につい て概観し，その機械的性質の特徵を整理した上で応力度Uずみ度関 係の簡単なモデル化を行う。その後このモデル化した応力度Uずみ 度関係を用いて，等曲げを受ける梁を対象に塑性変形能力評価を試 みる。そして本研究で提案している塑性域を反映した二次勾配と降 伏応力度を最大耐力時のひずみ度を参照しながら各鋼材ごとに算出 する。最後に本研究で提案している評価方法と従来の評価方法との 比較検討を行い，本研究の評価方法により各種鋼材を用いた場合に おいても統一的な評価が可能であることを示す。

\section{§2 . 本研究で提案する評価因子と㫕の評価因子が部材の塑性变形 能力に与える影響}

图 1 は，本研究で提案する部材の塑性変形能力を評価する際に用 いる降伏応力度と二次勾配の概念図を示している4)。このうな評 価因子をとる理由は，降伏点近傍の応力度ひずみ度関係は部材の大 変形時の挙動に大きな影響を及ほさないことと，なるべ簡便な方 法で評価するためである。

本研究で提案している降伏応力度と二次勾配が板の塑性変形能力 に与える影響について把握するために降伏応力度と二次勾配を変数 として数值解析を行う。解析モデルは図 2 に示すように等曲げモデ ルの圧縮側フランジ部分を取りだしたものを仮定するために，解析 の支持条件は困に示すように 3 辺が単純支持, 1 辺が自由端として 純圧縮を受けるものとする。解析で使用する材料特性は弾性勾配と 二次勾配を変数として bi-liniar 型を用いる。板の形状は図 2 中に示 すように設定し，幅厚比を8.3と6.0の2 種類のもので行っている。 また板厚方向を 5 分割, 板幅を 6 分割, 長さ方向を 18 分割して四辺 形要素を用いて解析を行っている。なお解析プログラムは ABA. QUS5.8-1を用いている。

解析結果を図 3 に示す。縦軸に板の塑性変形能力をとり, 横軸に 二次勾配の平方根をとって降伏応力度ごとに塑性変形能力を整理し

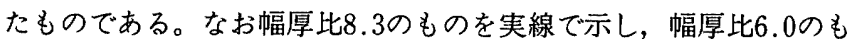
のを点線で示している。現在使用されている鋼材の二次勾配の平方 根の值は， 3 から 5 程度であることを考えると，この範囲ではどの 降伏応力度においても二次勾配の平方根と塑性変形能力はほぼ直線

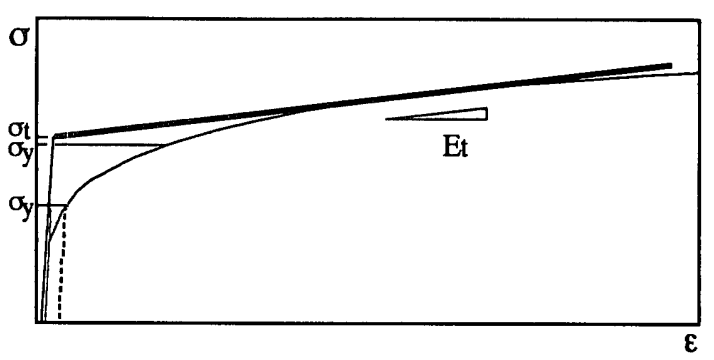

図 1 本研究で提案する鋼素材特性決定法

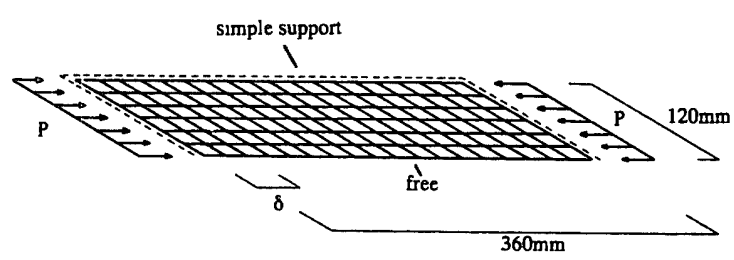

図 2 解析モデル

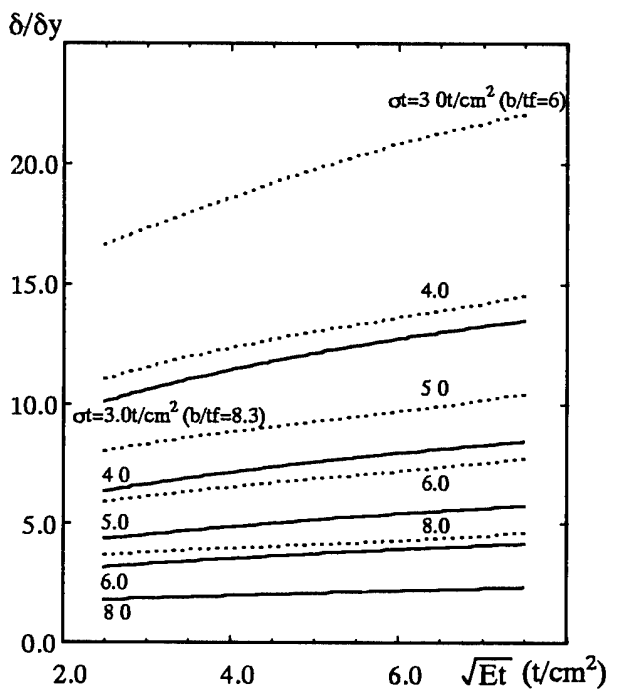

图 3 二次勾配が板の塑性変形能力に与える影響

関係にあり，二次勾配が増加するほど塑性変形能力も增加すること を示している。また幅厚比が小さくなると，降伏応力度が小さくな るにつれてその直線の勾配は大きくなっている。このようなことか ら降伏応力度が小さいものほど, 二次勾配がその塑性変形能力に影 響を与えることがわかり，望性変形能力を評価する際には二次勾配 を考慮する必要がある。

§3. 各種鋼材における塑性变形能力評洒のための評価因子の抽出 3.1 各種鋼材の材料特性の把握と応力度ひずみ度関係のモデル化

本研究で対象とする鋼材は, 建築分野において現在広く使用され ているもの及び使用が検討されているものを対象とする。ここでは， その代表的なものとして, SS400, SM490，SA440，HT590，HT780 を取り扱う。これら鋼材の機械的性質については著者等が最近数年 にわたり様々な実験を行った材料試験結果から収集した。採取した 試験片は板厚 $6 \mathrm{~mm}$ 以上の平板あるいは $\mathrm{H}$ 形鋼を構成する板要素 から切り出したものに限定している。またいずれも JIS1A 号引張試 

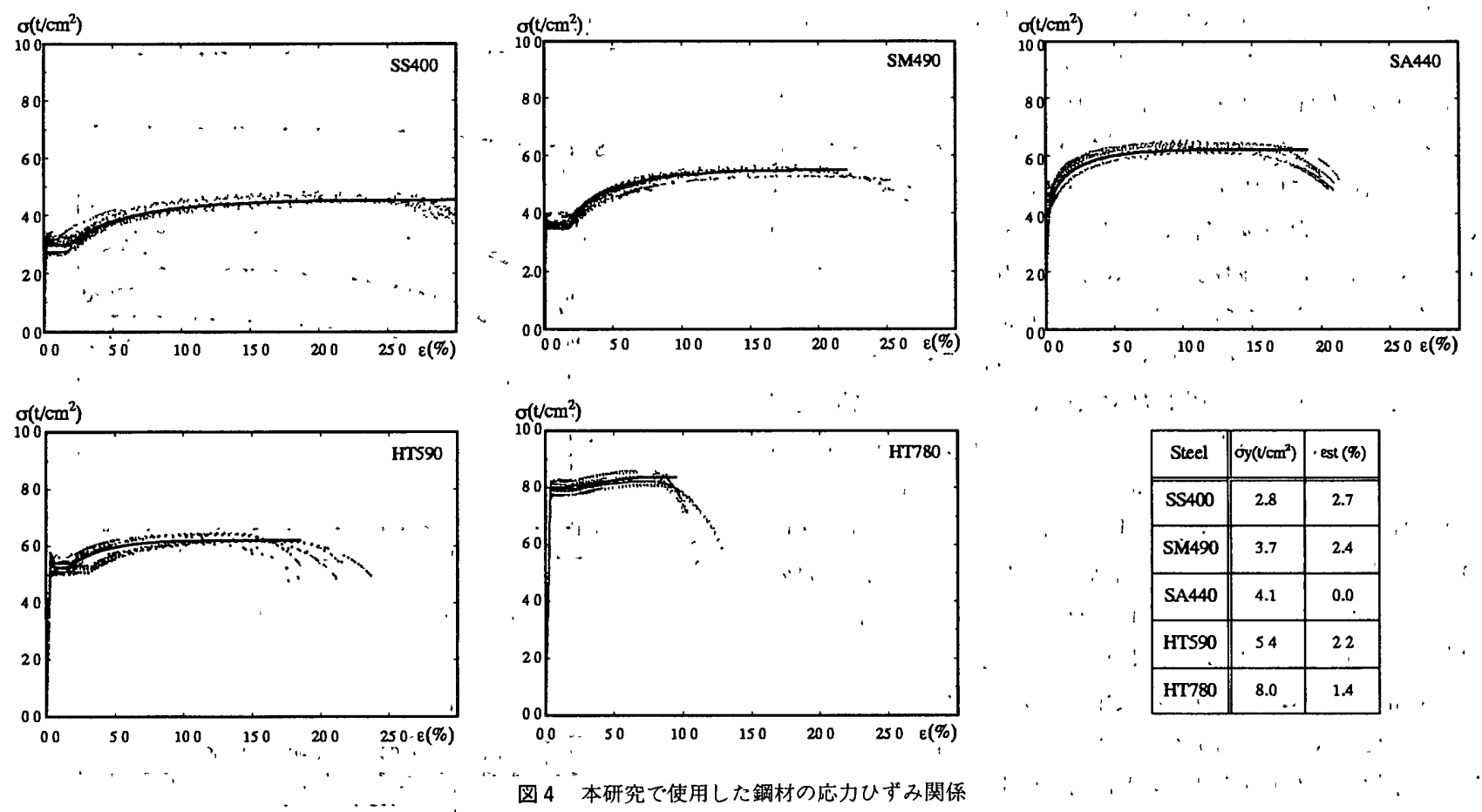

\begin{tabular}{|c||c|c|}
\hline Steel & dy $\left(\mathrm{Vcm}^{2}\right)$ & est $(\%)$ \\
\hline \hline SS400 & 2.8 & 2.7 \\
\hline SM490 & 3.7 & 2.4 \\
\hline SA440 & 4.1 & 0.0 \\
\hline HTS90 & 54 & 22 \\
\hline HT780 & 8.0 & 1.4 \\
\hline
\end{tabular}

験片による結果である。その応力度Uずみ度関係を図 4 に示す。ま たこれらの鋼材が有する機械的性質を平均值で表に示す。

これらの材料試験結果をもとに本研究の数值解析に用いる鋼材の 応力度ひずみ度関係のモデル化を行った。まず各鋼材について, 降 伏応力度 $\sigma y$ とUずみ硬化開始Uずみ $\varepsilon_{s t}$ を決定した。 $\sigma y$ は図 4 で 平均した值を近似的に表 1 中に示す值にして, 降伏棚の長さは, SS400, SM490, SA440, HT590．HT780のそれぞれの降伏びずみ の19，14，8，4として，Uずみ硬化開始Uずみを表 1 中のように 決定した。またびすみ硬化開始以降の曲線に関してほ对数関数を使 用することにしで以下のような式(1)で表した。

$$
\sigma=\alpha \cdot \log (1+\beta \cdot \varepsilon)
$$

鋼材の応力度Uずみ度曲線の数式表現については分数関数式, $n$ 乗硬化式, Menegotto-pinto Model, 修正 Menegotto-pinto Model, Ramberg-Osgood Model などの数式表現があり, 文献 6)，8） 〜11) 等で紹介ざれ, またこれらの式と様々な鋼材の材料試験結果と の比較を行っている。このような式を利用することにより正確な数 式表現が可能であるが, 本研究ではなるべく簡便にすべての鋼材に 適応できる.ものとして対数関数を採用した。この対数関数は真応力 と对数Uずみの関係で取り扱うている。この式中の係数 $\alpha, \beta$ に関し では, 表 1 中に示している。このようにモデル化した曲線を図 4 中 の実線で示す。モデル化した応力ひずみ度関係は引張試験結果との 対応もよく，各鋼材の塑性域での材料特性を良く反映した形になっ ている。

\section{$3: 2$ 塑性変形能力評価因子の抽出}

ここでは前節でモデル化した鋼材特性を゙用いて数值解析を行い, 塑性変形能力評価因子の抽出を行う。まず本研究における数值解析 の娈当性を示すために, 文献 4) で行った実験結果と数值解析どの対 応を検証する。解析で用いた材料定数は文献 4)で行った材料試験結 果を使用している。なお解析プログラムは ABAQUS5.8-1を用いて いる。図 5 に実験結果と数值解析結果と.の対応を示す。実験結果と

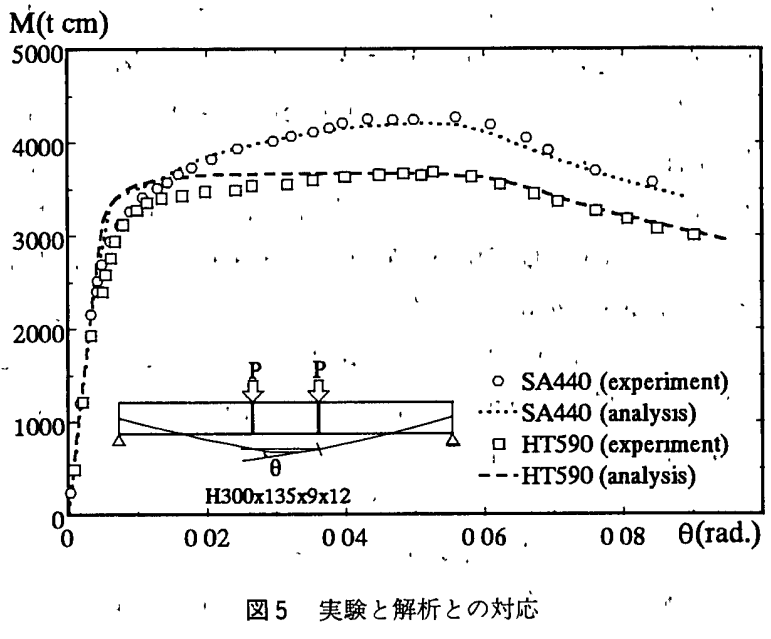

解析結果は概ね良い对応を示しており，本解析は妥当であると言え る。

、次に前節でモデル化した鋼材特性を用いて数值解析を行う。再度 本研究の数值解析で使用する各鋼材の材料特性を図 6 に示す。また 数值解析モデルは, 基本的なフランジ局部座屈性状を捉えるために, 図 7 に示す 4 点曲げを受ける $\mathrm{H}$ 形鋼梁であり, 本研究で対象として いるのは解析モデル中央の等曲げを受ける部分である。解析モデル の形状を図 7 の図中に示す。そしてフランジ板厚を変えるこ・とで適 宜フラン゙ジ幅厚比を変数にして数值解析を行う。また板厚方向を 5 分割, ·梁幅を10分割, “梁せいを20分割, : 解析モデル中央の等曲げを 受ける部分の長さを40分割して四辺形要素を用いて解析を行ってい る。なお数值計算の簡略のため, 試験体の中央を対称条件に設定し て数值解析を行っている。また横方向への移動を拘束するために圧 縮フランジとウェブの接合線上の節点を適宜拘束している。

'各種鋼材及びフランジ幅厚比を変化させて行った数值解析結果を もとに文献 4)の方法に従い最大耐力時のUずみ度を座届Uずみ 
$\left(\varepsilon_{\max }\right)$ と定義する。この $\varepsilon_{\max }$ をもとに, 本研究における塑性変形能力 評価因子を決定する。ただし $\varepsilon_{\max }$ は試験部分長さ中央の圧縮フラン ジ局部座屈発生位置での要素の表亭のひずみ度を平均した值であ る。この $\varepsilon_{\max }$ とフランジ幅厚比の関係を示しているのが図 8 であ る。黒印は各鋼材の座屈Uずみがひずみ硬化開始Uずみよりも大き いものを示し，また白抜き印は座屈Uずみがそれよりも小さいもの を示している。また点線および奉線は，座屈Uずみがしずみ硬化開 始ひずみよりも大きいものを对象とした回帰曲線である。この座屈 Uずみを用いて本研究で提案する二次勾配を算出するためのUずみ 度の範囲を決定する。また図中には文献12)に示されている幅厚比制 限を参照して記載している。各鋼材ごとの幅厚比規定值を表 1 に示 している。ただしすべて F 值換算により，規定值を算出している。 全体の傾向として降伏応力度の低い鋼材ほど座屈ひずみが大きい ものの，各鋼材の座屈ひずみの增加割合は降伏応力度の低い鋼材の ものほど緩やかになっている。降伏棚を有する鋼材では白抜き印と 黒印を境に座屈ひずみの值が急激に增している。その急激に増すと ころの座屈ひずみはほほほすずみ硬化開始Uずみに相当する。そし てUずみ硬化に入って座屈する時の幅厚比のものは降伏棚で座屈す る時の幅厚比のものよりも塑性変形能力が向上しており, 塑性変形 能力を十分に有するものになる。このようなことから二次勾配を決 定する場合にはUずみ硬化開始ひずみ以降で座屈Uずみの範囲でと ることが塑性域での二次勾配として捉えることができる。

二次勾配を算出するための座屈ひずみの範囲を決定するために, 便宜上文献12）で示されている幅厚比規定を参考にする。二次勾配 を決めるための座屈Uずみの範囲を本研究では四中に示すように $\mathrm{FB}$ ランクに相当する幅厚比の座屈Uずみと FA ランクに相当する 幅厚比の座屈ひずみの範囲の 2 倍とした。そのときの幅厚比を FA' とする。この幅厚比の範囲は建築構造用部材としてよく用いられる 標準の形鋼の幅厚比の範囲に相当する。その幅厚比の範囲に相当す るUずみの範囲を表 2 に示す。このUずみの範囲は応力度Uずみ度 関係と比較するとUずみ硬化開始Uずみ付近から始まっており，降 伏応力度が高い鋼材ほど，その範囲は大きくなっている。そしてこ のひずみの範囲で二次勾配をとることにより,本研究で提案している 手法で部材の望性変形能力を評価するときに良い对応を示している。

図 8 で決定した範囲をもとに本研究で提案する降伏応力度 $(\sigma t)$ と 二次勾配 $(E t)$ を決定する。二次勾配は各鋼材において表 2 で示した 範囲における応力度ひずみ度関係より最小二乗法を用いて回帰直線 を算出して，その直線の勾配を二次勾配 $(E t)$ とする。そして図 1 に 示す手法により算出した直線と弾性線を延長し交わった点を降伏応 力度 $(\sigma t)$ としている。以上の方法で求めたものを図 9 に示す。図中 の実線は各鋼材毎に求めた二次勾配を示している。また表 2 にその 算定した結果を示す。降伏棚を有する鋼材の降伏応力度 $(\sigma t)$ は従来 の降伏応力度とほほ同じ值を示すが, 降伏棚を持たないSA440の降 伏応力度 $(\sigma t)$ は従来の降伏応力度の值と違ったものとなっている。

本研究の評価方法は, 現在使用されている鋼材あるいは使用段階 にきている鋼材を対象として鋼材の応力度Uずみ度関係により簡便 な方法で求められる評価因子により部材の塑性変形能力を統一的に 評価することを目的としたものである。また降伏応力度と二次勾配 を別々な評価因子として捉えるのではなく，同時に扱うことにより 評価するものである。その鋼材を使用した場合の幅厚比制限值をも

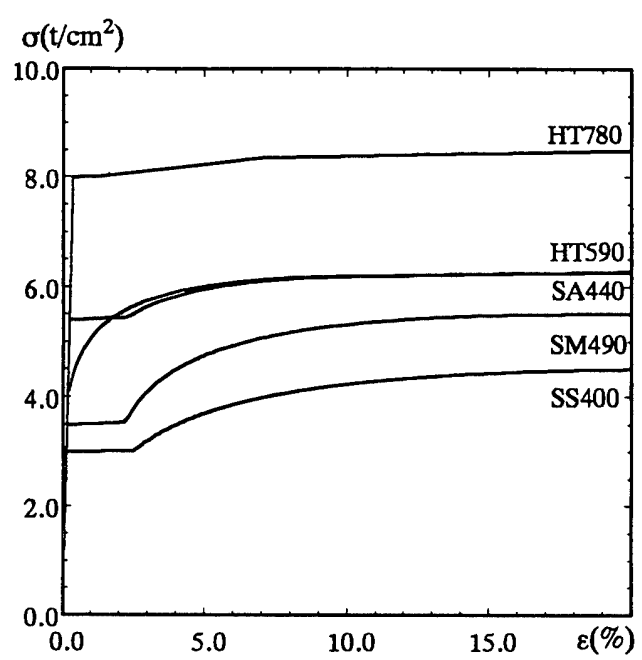

図 6 解析に使用する鋼材の解析モデル

表 1 解析で使用した鋼材の材料定数

\begin{tabular}{|c|c|c|c|c|c|}
\hline Stecl & SS 400 & SM490 & SA440 & HTS90 & HT780 \\
\hline$\theta y\left(v e \mathrm{ctr}^{2}\right)$ & 3.0 & 3.5 & 40 & 5.5 & 8.0 \\
\hline Est(\%) & 2.7 & 2.4 & 0.0 & 22 & 1.4 \\
\hline $\operatorname{cu}(\%)$ & 230 & 17.0 & 115 & 115 & 7.0 \\
\hline$\alpha$ & 2.4 & 3.4 & 1.8 & 1.8 & 0.2 \\
\hline$\beta$ & 300 & 100 & 500 & 500 & 190 \\
\hline$F^{*}+1$ & 8.1 & 7.5 & 6.9 & 59 & 4.9 \\
\hline $\mathrm{FB}^{*} 1$ & 9.8 & 9.1 & 8.5 & 72 & 6.0 \\
\hline
\end{tabular}

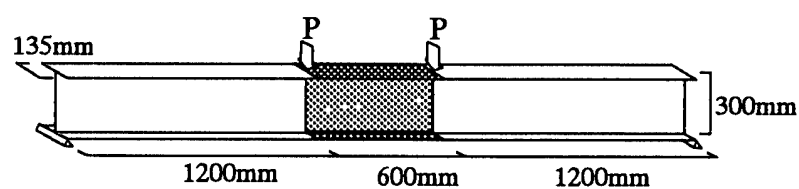

図 7 解析モデル

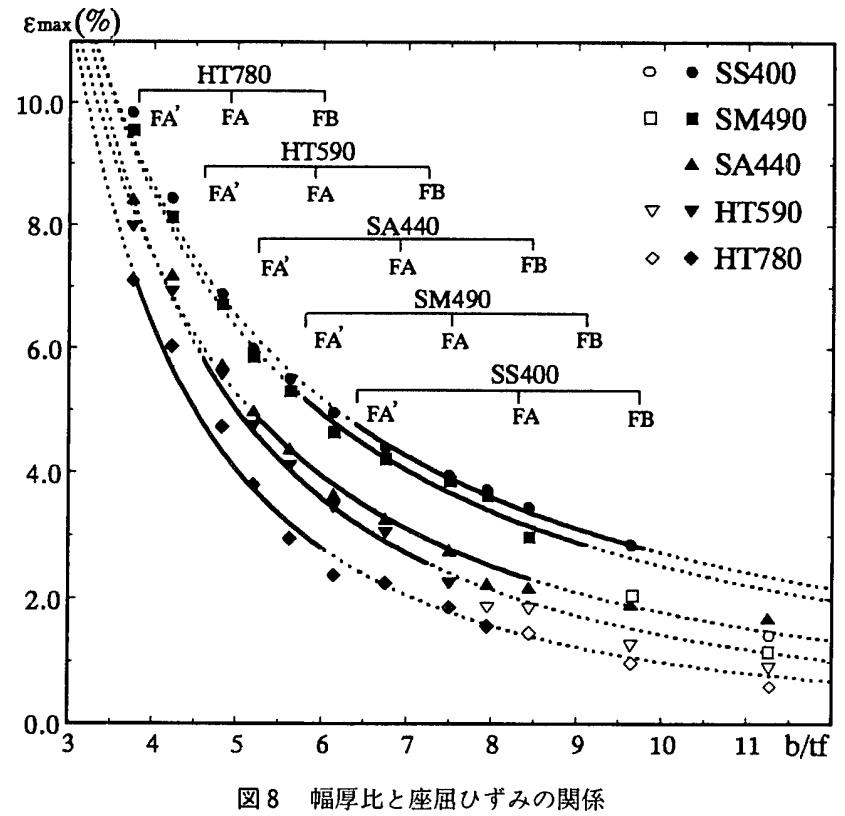




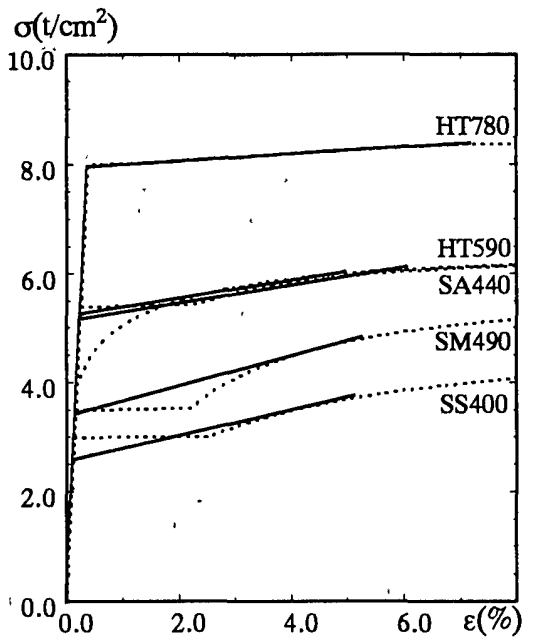

図 9 塑性域を考虑した二次勾配と降伏応力度

表 2 塑性変形能力評価因子

\begin{tabular}{|c||c|c|c|c|c|}
\hline Steel & SS400 & SM490 & SA440 & HTS90 & HT780 \\
\hline \hline or $\left(\mathrm{Vcm}^{2}\right)$ & 26 & 3.5 & 5.3 & 52 & 8.0 \\
\hline Et(V $\left.\mathrm{cm}^{2}\right)$ & 21 & 23 & 16 & 16 & 8 \\
\hline range(\%) & $2.8-4.8$ & $2.9 \sim 52$ & $2.3-43$ & $2.6-5.9$ & $28-71$. \\
\hline
\end{tabular}

とにして決定される応力度ひずみ度曲線の範囲での平均勾配をその 鋼材の二次勾配として扱い，その二次勾配と二次勾配を考慮して得 られる降伏応力度の 2 つの因子を用いて幅厚比を修正し，その幅厚 比で部材の望性変形能力を評価する。

\section{§4．各種鋼材を用いた部材の塑性変形能力評価}

\section{1 従来の評価方法と本研究で提案する評価方法との比較}

図10，11は横軸にフランジ幅厚比を変数としてて塑性変形能力を整 理したものである。図10の横軸には通常用いられる降伏応力度と弾 性係数を考慮して得られる等価幅厚比を用いている。これに对して 図11の横軸には，本研究で提案している塑性域を反映した二次勾配
$(E t)$ と降伏応力度 $(\sigma t)$ を用いて幅厚比に修正を加えたものである。 なお, 縦軸の荷重を無次元化するときの降伏応力度は本研究で提案 している塑性域を反映した降伏応力度を用いている。

図10では各鋼材ごとに何らかの曲線に近似しており，鋼材毎に幅 厚比を用いて塑性変形能力を評価することは可能である。しかし鋼 材間で比較してみると, 図11と比較してばらつきがみられる。この 図10の横軸に用いられている等価幅厚比は, 板要素の座屈応力度が 指標となっていることから鋼材の塑性域での鋼材の材料特性が十分 反映されず,・その結果として図11と比較してばらつきがみられる。 一方図11では，図10に比べて良い対応を示しており，何らかの近似 曲線で示すことができる。従って塑性変形能力を評価する際には本 研究で提案している塑性域を反映した二次勾配 $(E t)$ )と降伏応力度 $(\sigma t)$ で幅厚比を修正したものを用いることが有効であることがわか る。そして点線はすべての鋼材を対象としてひずみ硬化開始ひずみ 以降で座屈したものを近似曲線で示したものである。本研究ではこ の近似曲線を梁の塑性変形能力を統一的に評価する式として以下の (2)式を提案する。

$$
\theta / \theta p=1.5 \times 10^{-2} \cdot\left(\frac{b}{t f} \sqrt{\frac{\sigma t}{E t}}\right)^{-2}
$$

二次勾配を算出するための座屈ひずみの範囲を決定するために， 便宜上文献12) で示している幅厚比規定を参考にしている。その決定 した座屈Uずみの範囲以下にある白抜き印で示す降伏棚で座屈した 幅厚比においても一部で近似曲線から離れているものの, 従来の評 価方法に比べて良い对応を示している。，またその決定した座屈Uず みの範囲以上の座屈Uずみに相当する幅厚比においても，近似曲線 と良い対応を示している。つまりある限定した座屈Uずみの範囲で 二次勾配を算出したが；その決定した座屈ひずみの範囲外で座屈す る幅厚比の塑性変形能力を評価する上でも式(2)で示す近似曲線で対 応できることを示している。このことは本研究で提案している二次 勾配は弾性剛性と塑性域の剛性とが混在する降伏棚領域において も，またその座屈ひずみ範囲以上の領域の剛性においても奶応して いることを示し, 塑性域での平均した剛性として捉えることができ

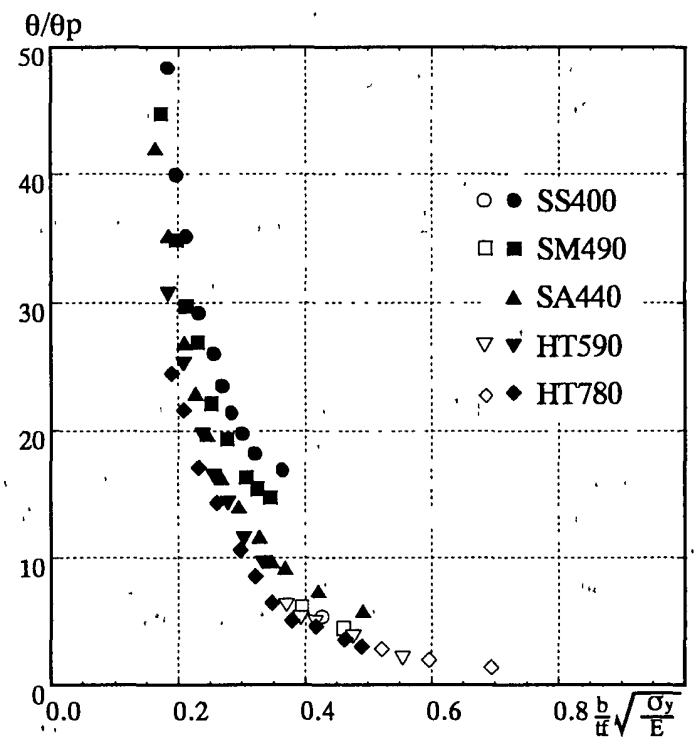

図10 通常の方法を用いたときの塑性変形能力評価

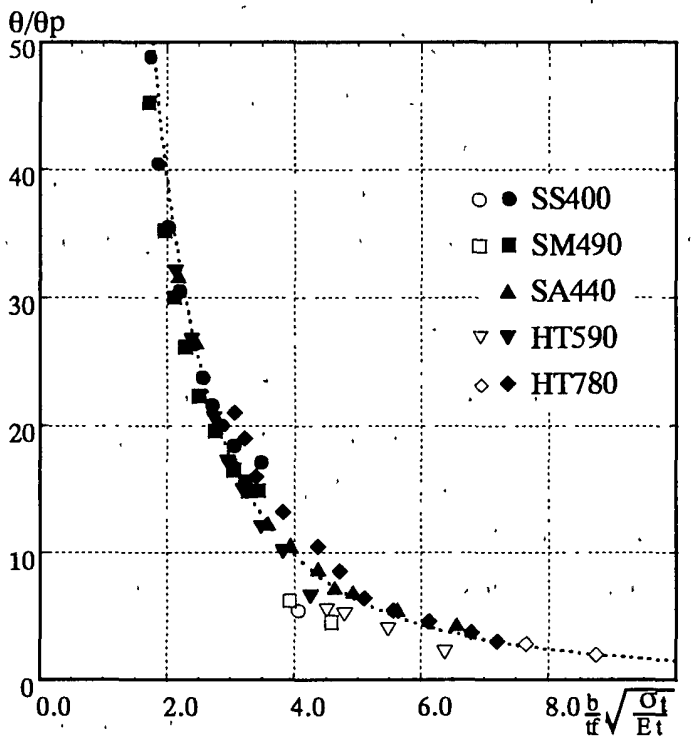

図11 本研究で提案する塑性変形能力評価 
る。このようなことから，本研究で示す座屈Uずみの範囲で二次勾 配を決定することはかなり有効であることを示している。

\section{2 無次元化荷重变位関係に及ぼす降伏応力度の影響}

図12，13に解析で行った無次元化荷重変位関係を示す。図12は降 伏応力度と弾性勾配を評価の指標として用いている等価幅厚比の值 が0.3付近での各鋼材の無次元化荷重変位関係を示している。なお無 次元化を行う際は従来の方法で得られる降伏応力度を用いている。 一方, 図13は本研究で提案している塑性域を反映した二次勾配 $(E t)$ と降伏応力度 $(\sigma t)$ で幅厚比を修正したときの值が3.2付近のときの 各鋼材の無次元化荷重変位関係を示している。そして無次元化を行 う際は本研究で提案している降伏応力度 $(\sigma t)$ を用いている。また縦 軸の荷重は試験体部分に加わるモーメントを全塑性モーメントで, 横軸の変位は端部回転角を全塑性モーメント時の弾性回転角でそれ ぞれ無次元化したものである。なお図中の、は最大耐力点を示して いる。図12では従来の降伏応力度を用いているので，すへての鋼材 において線形関係から離れるところは同じであるが，その後の塑性 域に入ってからの挙動は鋼材間においてかなり違うものとなってお $\eta$, 各種鋼材間の最大耐力時変位量, 最大耐力に大きな差が現れて いる。このことから降伏応力度のみを用いて部材の塑性変形能力を 評価することは，塑性域での鋼材の材料特性を反映しておらず，そ の結果として無次元化荷重変位関係において各鋼材間において大き な差が生じることになる。

これに对して図13に示す無次元化荷重変位関係では線形関係から 最大耐力までの挙動は違うものの, 最大耐力時変位量, 最大耐力は 図11と比較して各鋼材間の差異がなくなっている。従って本研究で 提案する塑性域を反映した二次勾配と降伏応力度を用いることによ ク，降伏応力度のみを用いた従来の評価方法に比べてよい对応を示 している。

\section{$\S 5$. 結}

本研究は, 数值解析を通して文献 4 )で提案している評価方法の対 象領域を現在建築用部材として使用されているあるいは使用が検討 されている鋼材に広げて，各鋼材を用いた場合の部材の統一的な塑 性変形能力評価を試みた。その際に降伏応力度と二次勾配が板要素 の塑性変形能力に与える影響について検討を行い，降伏応力度ばか クでなく，二次勾配を考慮して塑性変形能力を評価する必要がある ことを示した。さらに各種鋼材ごとに塑性変形能力を評価するため の評価因子である塑性域を反映した二次勾配と降伏応力度を抽出し た。その中で二次勾配を決定するためのひずみ度の範囲について検 討し，この二次勾配が塑性域での平均勾配として捉えられることを 示した。最後に本研究で提案する塑性域を反映した二次勾配と降伏 応力度の二つの評価因子により修正している幅厚比で部材の塑性変 形能力を評価したものと従来の降伏応力度により修正している等価 幅厚比で部材の塑性変形能力を評洒したものとの比較を行い, 本研 究で提案する評価方法が従来の評価方法よりもよい対応を示し各種 鋼材間における統一的な評価が可能であることを示した。

\footnotetext{
参考文献

1）加藤 勉 高張力龬の高層建築物への利用, 製鉄研究, 第 321 号, pp 1 7,
}

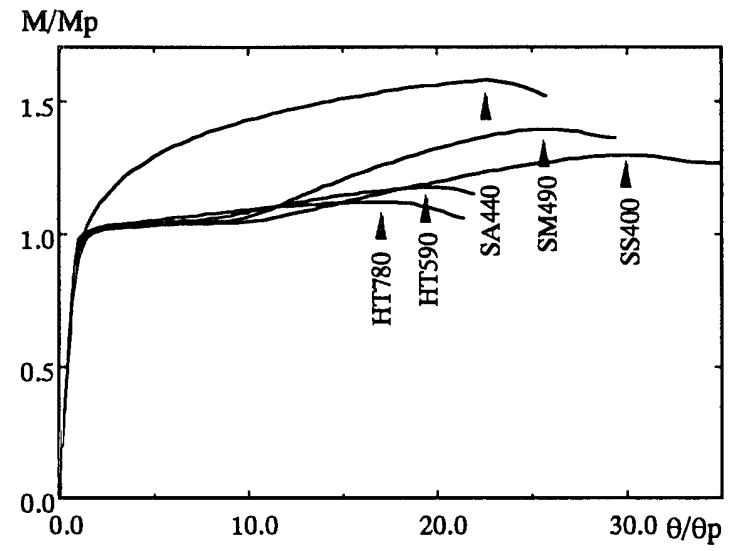

図12 $\sigma y$ を用いた場合の無次元化荷重変位関係

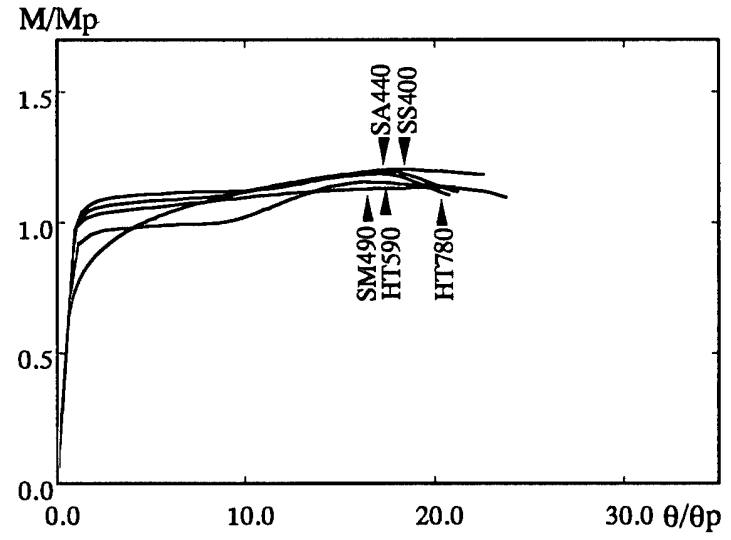

図13 $\sigma t$ を用いた場合の無次元化荷重変位関係

2）加藤 勉 . 建設用鋼材の降伏比について, 鉄と鋼, 第 6 号, pp 11 21, 1988

3）鈴木敏郎, 小河利行, 五十嵐規矩夫, 小幡 学 降伏比の異なる鋼材を用 いた高張力鋼梁の望性変形性能に関する研究, 日本建築学会構造系論文 集, No 476, pp 169 176, 199510

4）鈴木敏郎，五十嵐規矩夫，薩川恵一 鋼構造部材の塑性変形能力に及ほす 鋼素材特性の影響, 日本建築学会構造系諭文集, No 517, pp.141 148, 19993

5）小野徹郎, 尾崎 亮, 岩田 衛 補エネルギーによる素材特性と部材変形 性能に関する検討, 日本建築学会大会学術講演梗概集, pp 1139 1140, 1993.9

6）小野徹郎, 上之郷貫重, 吉田文久, 岩田 衛, 林 蜸一 金属系素材の素 材特性及び履歴挙動に関する研究，日本建築学会構造系論文集, No 498, pp.137 143, 1997.8

7）小野徽郎, 吉田文久 $\mathrm{H}$ 形断面短柱の変形性能に及ほす素材特性の影響 に関する研究その 1 , 日本建築学会構造系論文集, No. 503, pp.125 129, 19981

8）佐藤篤司, 小野徹郎 金属系菜材の応力一歪度関係の再現に対する相对的 評価及U゙考察 (その 1 ), 日本建築学会大会学術講演梗概集, pp.321 322, 1999.9

9）佐藤篤司, 小野徽郎, 加古康也 金属系素材の履歴型応力一歪度関俰の定 式化, 日本建築学会大会学術講演梗概集, pp 583 584, 1998.9

10）青木博文, 增田正之 素材引張試験結果による構造用鋼材の力学的性質に 関する統計的調査, 日本建築学会構造系論文集, No 358, pp 125 129, 198512

11）青木博文, 加藤 勉, 丁 峰 高炉厚板鋼板の機械的性質と応力Uずみ 関係の数式表示, 日本建築学会構造系論文集, No 398, pp 73 85, 1989.4

12）日本建築センター 建築物の構造規定, 1994

（1999年12月10日原稿受理，2000年 4 月17日採用決定） 